Gut, 1977, 18, 351-355

\title{
Escherichia coli serotypes throughout the gastrointestinal tract of patients with intestinal disorders
}

\author{
SOAD TABAQCHALI, 1 ALISON HOWARD, C. H. TEOH-CHAN, K. A. \\ BETTELHEIM, AND S. L. GORBACH ${ }^{2}$
}

From the Department of Medical Microbiology, St Bartholomew's Hospital, London, and the Department of Medicine, Royal Postgraduate Medical School, Hammersmith Hospital, London

SUMmARY The $\mathrm{O}$ and $\mathrm{H}$ serotypes of Escherichia coli that were present along the entire length of the gastrointestinal tract of patients with small intestinal bacterial overgrowth were studied. Multiple sero- and biotypes were represented, although usually a single serotype predominated in each patient. In a number of cases the different $\mathrm{O}: \mathrm{H}$ serotypes were antigenically related indicating that antigenic degradation was occurring. The serotypes isolated from the stomach and small intestine were represented in the faeces. In general, within the limitations of this study, there appears to be a stable ecosystem in each patient and it may require specific oral antibiotics to alter it.

Improved bacteriological techniques have permitted more detailed studies of the microecology of the small intestine in man. However, it is still not known whether the whole small intestine is colonised by a single strain of bacteria or multiple strains of this species. Esch. coli is the organism most widely studied because there exists an international system of serotyping based on 163 different $O$ antigens and 55 different $\mathrm{H}$ antigens isolated from human and animal sources.

All previous studies on the different serotypes of Esch. coli that we found in the gastrointestinal tract of man have concentrated on examining faecal specimens only (Shooter, et al., 1970, Cooke et al., 1972), and there are no reports on the types and distributions of the organisms in the small bowel and their relationship to the faecal flora. As the normal small intestine in man usually harbours a Gram-positive microflora and the enterobacteria and the anaerobic Gram-negative bacteria appear only distally (Gorbach et al., 1967, Drasar et al., 1969), the best conditions in which to study the distribution of Esch. coli in the small bowel were patients with small intestinal bacterial overgrowth, the so-called

\footnotetext{
${ }^{1}$ Address for reprint requests: S.T., Department of Medical Microbiology, St Bartholomew's Hospital, London, EC1A 7BE.

2Present address: New England Medical Center Hospital, Boston, Mass., USA.

Received for publication 1 November 1976
}

stagnant loop syndrome. It is well established that, under these conditions, the small intestine is colonised by bacteria which are qualitatively similar to the faecal flora and often reach high concentrations (Gorbach and Tabaqchali, 1969). In addition, there remain certain unanswered questions concerning the intestinal flora in these patients: is the colonisation of the small bowel by Esch. coli retrograde from lower sites or, alternatively, are these organisms continually being introduced by the oral route from the environment?

In this paper, therefore, we report on the serotypes of Esch. coli present in the entire length of the gastrointestinal tract in patients with bacterial overgrowth.

\section{Methods}

\section{PATIENTS STUDIED}

Seven patients with a variety of gastrointestinal disorders were studied (Table 1). All had evidence of small intestinal bacterial overgrowth. The types and concentration of the bacteria at different levels of the gastrointestinal tract in patients 1-6were reported elsewhere (Gorbach and Tabaqchali, 1969). Patients 1 and 2 were given oral tetracycline and patients 2 and 3 oral lincomycin, and their effect on the $E$. coli serotypes was studied.

SAMPLES

Patients 1-7 (Table 1) were intubated perorally with 
Table 1 Clinical data of patients studied

\begin{tabular}{|c|c|c|c|}
\hline Case no. & $\begin{array}{l}\text { Age and sex } \\
(y r)\end{array}$ & Clinical diagnosis & $\begin{array}{l}\text { No. of E. coli } \\
\text { strains tested }\end{array}$ \\
\hline 1 (13) & $53 \mathbf{M}$ & $\begin{array}{l}\text { Ileal stricture, Crohn's disease. Resection of } 31.5 \mathrm{~cm} \text { of ileum. Ileo-transverse } \\
\text { colonic anastomosis }\end{array}$ & 150 \\
\hline $2(8)$ & $51 F$ & Multiple duodenal and jejunal diverticulosis (diabetes mellitus) & 108 \\
\hline $3(9)$ & 80 & Multiple duodenal and jejunal diverticulosis, Billroth I gastrectomy & 60 \\
\hline $4(2)$ & 55 & Polya partial gastrectomy & 46 \\
\hline 5 (15) & 78 & $\begin{array}{l}\text { Massive resection of small intestine }(35.5 \mathrm{~cm} \text { jejunum remaining anstomosed } \\
\text { to transverse colon) }\end{array}$ & 38 \\
\hline $6(14)$ & 48 & Ileal resection $(0.9 \mathrm{~m}$ of terminal ileum) & 36 \\
\hline 7 & 25 & Crohn's disease-multiple strictures & 90 \\
\hline
\end{tabular}

Figures in parentheses represent case numbers relating to previous study (Gorbach and Tabaqchali, 1969).

a double lumen polyethylene tube (diameter $1.8 \mathrm{~mm}$, length $400 \mathrm{~cm}$ ) under fluoroscopic control. Specimens were obtained from the stomach and from different levels of the gastrointestinal tract. Faecal samples were also obtained from these patients.

\section{BACTERIAL CULTURE}

The above specimens were cultured on McConkey's medium and five to 10 colonies including the various colonial types were examined from each site. The total number of isolates examined from each patient is given in Table 1.

The organisms picked were considered to be $E$. coli on the basis of their ability to ferment glucose with the production of acid and gas, lactose with the production of acid, to produce indole as well as their inability to produce urease or utilise citrate as sole source of carbon (Cooke et al., 1969).

\section{SEROLOGY}

The strains of $E$. coli were $O$ serotyped using 163 antisera by methods described by Bettelheim and Taylor (1969) and the automatic serotyping machine was employed (Bettelheim et al., 1975). The H antigens of all motile strains were determined by the method of Chandler and Bettelheim (1974). Strains which consistently did not develop motility after serial passage through semi-solid medium and after being observed microscopically as not motile were considered to be non-motile and classed as $\mathrm{H}-$.

\section{Biotyping and antibiotic sensitivity testing}

These were performed as described by Bettelheim et al. (1974a). The carbohydrate substrates used were: dulcitol $(\mathrm{Du})$, maltose $(\mathrm{Ma})$, raffinose (Rf), sorbose (So), sucrose $(\mathbf{S c})$, and salicin $(\mathbf{S l})$. Some strains gave variable results with salicin and these are marked as: $\mathrm{Sl}(\mathrm{v})$. (The above abbreviations are used in the result section.) The antibiotics tested were ampicillin, streptomycin, tetracycline, chloramphenicol, kanamycin, sulphonamide, nalidixic acid, trimethoprim, and gentamicin.

\section{Results}

One hundred and fifty strains of $E$. coli were isolated from the different sites of the gastrointestinal tract of patient 1 . These were serotyped and biotyped and fell into 10 subgroups which are labelled $A$ to $J$ for the purpose of this study, as shown in Table 2. The distribution of the types A-J in the intestinal and faecal specimens from this patient are shown in Table 3.

Serotypes R.H32(A), R.H19(B) and 0104.H19(C) were isolated from the stomach on the first day as well as from the stool specimen which was taken three days later. These types were also represented along the gastrointestinal tract for a period of at least three weeks (Table 3).

The types obtained from the intestinal mucosal biopsy after vigorous washings were $\mathrm{A}$ and $\mathrm{E}$ (R.H32). Type A appears to have been present in the lumen as well as adherent to the mucosa, whereas type $\mathrm{E}$ was isolated only from the mucosa. On the $13 / 2$ not only type A but also type F (R.H32), which is a biochemical variant of type $E$, were isolated from the jejunum and faeces. The patient was then treated with tetracycline $(250 \mathrm{mg}$ six hourly) for seven days and was studied again six weeks later on

Table 2 Different sero- and biotypes of $\mathrm{E}$. coli isolated from patient 1

\begin{tabular}{lll}
\hline Subgroup & $\begin{array}{l}\text { Serotype } \\
\text { Oand H }\end{array}$ & Biotype \\
\hline A & R.H32 & Rh,Sc,S1(v), Ma \\
B & R.H19 & Du, Rf, Rh, Sc, Ma \\
C & O104.H19 & Du, Rf, Rh, Sc, Ma \\
D & Ont.H7 & Du, Rh, Sc, Ma \\
E & R.H32 & Du, Rf, Rh, Sc, Ma \\
F & R.H32 & Rh, Sl(v), Ma \\
G & R.H32 & Du, Rh, So, Ma \\
H & Ont.H32 & Rf, Rh, Sc, Ma \\
I & $0129 . H 30$ & Rf, Rh, Sc, Ma \\
J & $0129 . H-$ & Rf, Rh, Sc, Ma \\
\hline
\end{tabular}

R: rough. Ont.: non-typable. $\mathrm{H}-$ : non-motile. 
Table 3 Distribution of E. coli sero-and biotypes in various specimens taken from patient $1^{*}$

\begin{tabular}{|c|c|c|c|c|c|c|c|c|c|}
\hline \multirow[t]{2}{*}{ Site of specimen } & \multicolumn{9}{|c|}{ Date of sampling } \\
\hline & $26 \cdot 1$ & $27 \cdot 1$ & $29 \cdot 1$ & $6 \cdot 2$ & $13 \cdot 2$ & $15 \cdot 2$ & $25 / 4 \dagger$ & $26 / 4$ & $27 / 4$ \\
\hline Stomach & $\mathbf{A}, \mathbf{B}, \mathbf{C}$ & 一 & 一 & - & - & - & 一 & 一 & - \\
\hline Upper & $A, C$ & - & B & - & $\mathbf{A}, \mathbf{F}$ & - & H, I & I & - \\
\hline Biopsy & - & 一 & 一 & $\mathrm{A}, \mathrm{E}$ & - & - & - & - & - \\
\hline Lower & - & - & - & - & - & - & - & I, J & - \\
\hline Ileum & & & & & & & & & \\
\hline Mid & - & C & C & - & - & - & - & - & I, J \\
\hline Terminal & - & - & - & - & - & $\mathbf{F}$ & - & - & - \\
\hline Faeces & - & - & A, B, C, D & - & $\mathbf{F}$ & $F, G$ & - & - & I \\
\hline
\end{tabular}

* Total number of $E$. coli strains tested: 150.

†Six weeks after oral tetracycline ( $250 \mathrm{mg}$ six hourly) for one week.

See Table 2 for details of types listed as A-J.

- No specimen was obtained.

25/4. During this period there was a change in the types and new strains appeared (I and J; Table 2) in the lumen of the small intestine, jejunum, ileum, and in the faeces (Table 3). All the 150 strains were fully sensitive to all the antibiotics tested, even after antibiotic therapy with tetracycline.

From patient 2, $108 \mathrm{E}$. coli strains were tested. These were obtained from stomach, duodenum, upper jejunum, lower jejunum, and faeces and after oral antibiotic therapy (Table 4).

The main isolates from this patient were R.H4, 0102.H?, and 020.H4. From stomach, duodenum, and upper jejunum on the first day, the serotypes isolated were R.H4 and 0102.H?; on the following day the sample from the lower jejunum yielded 020.H4 and R.H4; the latter was also found in the stool specimen. When the patient was intubated on $10 / 5$, and after lincomycin therapy, R.H4 remained the main isolate throughout. There was no significant change in the serotypes after lincomycin, but there was after oral tetracycline therapy when no $E$. coli were isolated from all the specimens tested (Table 4).

The different $E$. coli serotypes isolated from the samples obtained from various sites of the gastrointestinal tract of patients 3-7 are shown in Table 5.

From patient 3, 60 strains of $E$. coli were isolated from stomach, duodenum, jejunum, ileum, and faeces. Only one serotype, Ont.H7, was found from all sites at all times. Repeat intubations four weeks later yielded the same $E$. coli serotype and there was no change after treatment with oral lincomycin (500 mg eight hourly) for seven days.

All 46 strains of $E$. coli isolated from patient 4 were 0104.H?. They were found over a period of nine days from upper and mid-jejunum, ileum, and faeces.

From patient 5, the main serotypes isolated from the stomach, duodenum, upper jejunum, and stool were $022 . H 1$ and R.H1. They all fermented rhamnose, sorbose, and maltose. Only some strains fermented dulcitol and salicin. They were all fully sensitive against all antibiotics tested.

Patient 6, over a period of three days, yielded mainly a serotype $05 . \mathrm{H} 7$. This was the main serotype isolated from mid-jejunum, lower jejunum, upper ileum, and stool specimens. Some of these strains

Table 4 Distribution of E. coli serotypes in specimens obtained from patient 2 (Table 1$)^{*}$

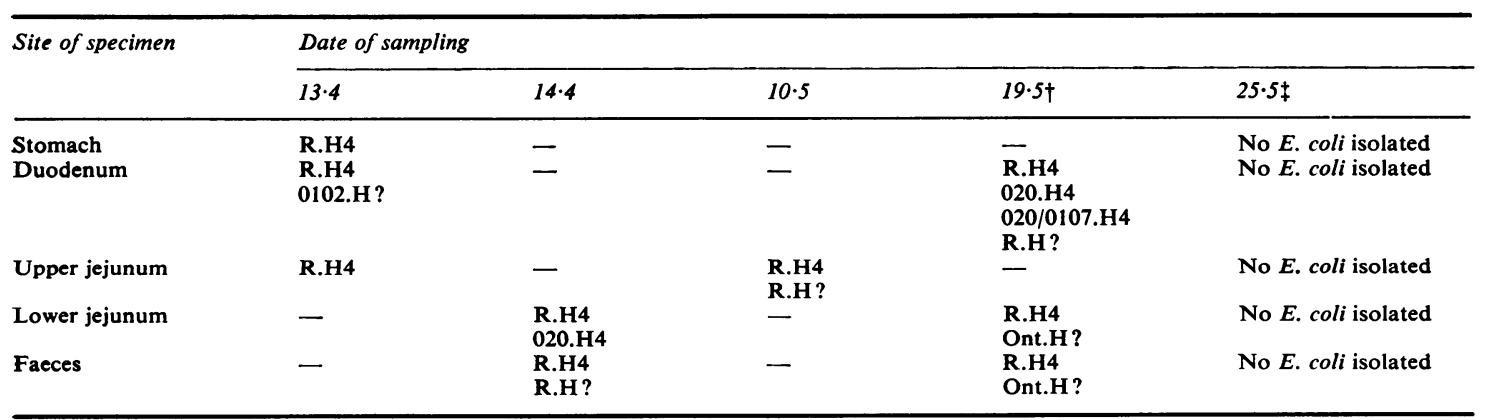

* Total number of $E$. coli strains tested was 108 .

+Lincomycin ( $500 \mathrm{mg}$ eight hourly) was given for nine days previously.

$\ddagger$ Tetracycline ( $250 \mathrm{mg}$ six hourly) was given for six days previously.

- No specimen was obtained. 
Table 5 E. coli serotypes isolated from different sites of gastrointestinal tract from patients 3-7

\begin{tabular}{|c|c|c|c|c|c|}
\hline & \multicolumn{5}{|c|}{ Patients (index no.) } \\
\hline & 3 & 4 & 5 & 6 & 7 \\
\hline $\begin{array}{l}\text { Dates of isolation } \\
\text { Total no. E. coli tested }\end{array}$ & $\begin{array}{l}6 / 3-25 / 4^{*} \\
60\end{array}$ & $\begin{array}{l}15-24 / 5 \\
46\end{array}$ & $\begin{array}{l}25-26 / 5 \\
38\end{array}$ & $\begin{array}{l}20-23 / 2 \\
36\end{array}$ & $\begin{array}{l}10-13 / 10 \\
90\end{array}$ \\
\hline \multicolumn{6}{|l|}{ Sites of specimen } \\
\hline Stomach & Ont.H7 & - & 022.H1, R.H1 & - & - \\
\hline $\begin{array}{l}\text { Duodenum } \\
\text { Jejunum }\end{array}$ & Ont.H7 & 一 & 022.H1 & - & Orel 21.H12,† R.H12 \\
\hline Upper & Ont.H7 & 0104.H? & 022.H1, R.H1 & 05.H7 & Orel 21.H12, R.H12, 021.H12 \\
\hline Lower & - & 0104.H? & - & $05 . \mathrm{H} 7$ & Orel 21.H12, 021.H12, Orel 21.H - \\
\hline \multicolumn{6}{|r|}{ Co } \\
\hline Mid & Ont.H7 & 0104.H? & - & $05 . \mathrm{H} 7$ & - \\
\hline Terminal & & 0104.H? & - & 05.H7, Orel 5.H7 & - \\
\hline Faeces & Ont.H7 & 0104.H? & R.H1 & $\begin{array}{l}\text { 05.H7, Orel 5.H7 } \\
\text { R.H32, Ont.H - }\end{array}$ & Orel 21.H12, 021.H12, R.H12 \\
\hline
\end{tabular}

* Repeat sampling on 11/4 and after oral lincomycin therapy on $25 / 4$ yielded the same serotype distribution.

fOrel $21=0$ antigen related to 021 but not identical with it by absorption studies.

$\ddagger$ R.H12 isolated on the second day only.

Table 6 Effect of food on E. coli serotypes present in small intestine

\begin{tabular}{|c|c|c|c|}
\hline $\begin{array}{l}\text { Patient } \\
\text { (index no.) }\end{array}$ & $\begin{array}{l}\text { Site of } \\
\text { isolation }\end{array}$ & Fasting & $\begin{array}{l}\text { Two hours } \\
\text { after meal }\end{array}$ \\
\hline 2 & $\begin{array}{l}\text { Duodenum } \\
\text { Jejunum }\end{array}$ & $\begin{array}{l}\text { R.H? } \\
\text { 020/0107.H4 } \\
\text { R.H4 } \\
\text { R.H? }\end{array}$ & $\begin{array}{l}\text { R.H4 } \\
\text { 020.H4 } \\
\text { R.H4 }\end{array}$ \\
\hline 5 & $\begin{array}{l}\text { Duodenum } \\
\text { Upper jejunum }\end{array}$ & $\begin{array}{l}\text { 022.H1 } \\
\text { R.H1 } \\
\text { 022.H1 } \\
\text { R.H }\end{array}$ & $\begin{array}{l}\text { 022.H1 } \\
\text { R.H1 }\end{array}$ \\
\hline 6 & $\begin{array}{l}\text { Mid jejunum } \\
\text { Mid ileum }\end{array}$ & $\begin{array}{l}05 . \mathrm{H7} \\
05 . \mathrm{H7}\end{array}$ & $\begin{array}{l}05 . \mathrm{H7} \\
05 . \mathrm{H7}\end{array}$ \\
\hline 7 & Upper jejunum & $\begin{array}{l}\text { Orel.21.H12 } \\
\text { R.H12 } \\
\text { 021.H12 }\end{array}$ & $\begin{array}{l}\text { Orel.21.H12 } \\
\text { R.H12 }\end{array}$ \\
\hline
\end{tabular}

were only related to 05 . Some rough strains with $\mathrm{H} 32$ antigen and non-motile strains were also isolated from stool.

Patient 7 had $90 \mathrm{E}$. coli isolates tested and only four serotypes were found. These were 021.H12, Orel.21.H12, a serotype related to 021 but not identical by absorption studies, a rough strain R.H12, and a non-motile strain: Orel.21.H-. Their distribution is given in Table 5. In the specimens from duodenum, upper and lower jejunum, and faeces the two types isolated were Orel.21.H12 and R.H12. The same types were isolated from the stool specimen on the following three days.

In Table 6 are given the results of the serotypes of $E$. coli isolated from four of the seven patients after a meal. There was no apparent change in the serotypes isolated from these specimens.

\section{Discussion}

The problems of investigating the microbial populations of the diseased bowel were discussed in earlier studies (Gorbach and Tabaqchali, 1969) and it was shown that multiple sampling at various levels gives a better understanding of the microbial ecology of the gastrointestinal tract. It was, therefore, considered that the additional information obtainable by $\mathrm{O}$ and $\mathrm{H}$ serotyping as well as biotyping and antibiotic resistance typing of the $E$. coli present might clarify further our understanding of this microbial ecosystem.

However, in this study as well as in the numerous other epidemiological studies in which the serotyping of $E$. coli strains was used as a means of correlating them with their environment (Bettelheim et al., 1974a, b; Boyer et al., 1975), the major problem is the difficulty of studying in detail sufficient numbers of strains from each specimen in order to give a definite pattern.

With over $160 \mathrm{O}$ types and $55 \mathrm{H}$ types accepted internationally, as well as numerous strains being $\mathbf{O}$ or $\mathbf{H}$ untypable, the problems of examining any large number of strains with all these antisera become virtually impossible. With all these obvious deficiencies, several points emerge from this study.

On the basis of the accepted $O / R$ variations and $\mathrm{H}+/ \mathrm{H}$ - variation, as well as some of the variations in the pattern of sugar fermentation (Bettelheim et al. $1974 a, b)$ one can consider that the 10 different serotypes and biotypes isolated from patient 1 , fall into four groups. Group 1 consists of Types A, E, F, G, and H; group 2 of B and C; group 3 of D only; and group 4 of $I$ and $J$ (Table 2).

In this patient there were similar groups of seroand biotypes present throughout the gastrointestinal tract from stomach to faeces during the earlier part of the study lasting from $26 / 1$ to $15 / 2$. However, six weeks after oral tetracycline therapy, there was recolonisation of the small bowel with $E$. coli (Gorbach and Tabaqchali, 1969) but with different 
serotypes. The earlier groups seem to have disappeared and were replaced by 0129 strains (group 4). The only serotype that might be considered related to the previous group after antibiotic therapy is $\mathbf{H}$, which was found in the upper jejunum only; the significance of its presence is uncertain. The serotypes obtained from the jejunal biopsy specimen were similar to those obtained from the intraluminal intestinal samples and faecal specimens, except that there was a difference in the biotyping in one of the strains which was isolated from the mucosa only.

One serotype appeared to predominate along the intestinal tract of patients 3-6 (Table 5), whereas all the serotypes isolated from patient 7 appear to be related. They seem to form a degradation series from 021.H12 through $\mathrm{O}$ related to $21 \mathrm{H} 12$ to R.H12. It is interesting to note that the samples obtained on the same day from the various sites indicate that the more degraded strains appear higher up in the intestine. The rough strain appears in the stool only on the next day.

Food did not have an effect on the serotypes already isolated from the four patients reported here (Table 6). Fasting and post-prandial samples yielded similar serotypes, even though food had caused a marked increase in the $E$. coli viable counts and also led to the appearance of the anaerobic Bacteroides $s p$. for the first time in the intestinal aspirates from patient 5 (Gorbach and Tabaqchali, 1969).

Tetracycline, a broad spectrum antibiotic given orally, appeared to have eradicated temporarily the $E$. coli from patient 2 (Table 4), and possibly from patient 1 , who was later colonised by different serotypes of $E$. coli (Table 3). Whereas lincomycin, known to be ineffective against aerobic gramnegative bacilli had no effect on the serotypes of $E$. coli in patients 2 and 3 , yet it eradicated the Bacteroides sp. isolated from the same samples (Gorbach and Tabaqchali, 1969).

Further studies are necessary, but it appears from these two patients that for effecting a change in the intestinal flora a specific antibiotic may be required.

No direct evidence of downward movement of serotypes was found, because a quantitative assessment of the distribution of $E$. coli types throughout the length of the gastrointestinal tract is not possible with the techniques currently available. In general, it appears that a different single serotype of $E$. coli predominates throughout the gastrointestinal tract of each of the patients studied. Nevertheless, the variety of serotypes encountered and the small number of patients studied preclude the drawing of any general conclusions.

We are very grateful to Professor C. C. Booth for his encouragement and for allowing us to study the patients under his care and to Professor R. A. Shooter for his advice throughout this work.

\section{References}

Bettelheim, K. A., Bushrod, F. M., Chandler, M. E., Trotman, R. E., and Byrne, K. C. (1975). An automatic method for serotyping Escherichia coli. Zentrablatt für Bakteriologie, Parasitenkunde Infektionskrankheiten und Hygiene, I. Abt. Orig., 230, 443-451.

Bettelheim, K. A. and Taylor, J. (1969). A study of Escherichia coli isolated from chronic urinary infection. Journal of Medical Microbiology, 2, 225-236.

Bettelheim, K. A., Teoh-Chan, C. H., Chandler, M. E., O'Farrell, S. M., Rahamin, L., Shaw, E. J., and Shooter, R. A. (1974a). Further studies of Escherichia coli in babies after normal delivery. Journal of Hygiene, 73, 277-285.

Bettelheim, K. A., Teoh-Chan, C. H., Chandler, M. E., O'Farrell, S. M., Rahamin, L., Shaw, E. J., and Shooter, R. A. (1974b). Spread of Escherichia coli colonizing newborn babies and their mothers. Journal of Hygiene, 73, 383-387.

Boyer, K. M., Petersen, N. J., Farzaneh, I., Pattison, C. P., Hart, M. C., and Maynard, J. E. (1975). An outbreak of gastroenteritis due to $E$. coli 0142 in a neonatal nursery. Journal of Pediatrics, 86, 919-927.

Chandler, M. E., and Bettelheim, K. A. (1974). A rapid method of identifying Escherichia coli $\mathbf{H}$ antigens. Zentrablatt für Bakteriologie, Parasitenkunde, Infektionskrankheiten und Hygiene, I. Abt. Orig., 229, 74-79.

Cooke, E. M., Ewins, S., and Shooter, R. A. (1969). Changing faecal population of Escherichia coli in hospital medical patients. British Medical Journal, 4, 593-595.

Cooke, E. M., Hettiaratchy, I. G. T., and Buck, A. C. (1972). Fate of ingested Escherichia coli in normal persons. Journal of Medical Microbiology, 5, 361-369.

Drasar, B. S., Shiner, M., and McLeod, G. M. (1969). Studies on the intestinal flora. I. The bacterial flora of the gastrointestinal tract in healthy and achlorhydric persons. Gastroenterology, 56, 71-79.

Gorbach, S. L., and Tabaqchali, S. (1969). Bacteria, bile and the small bowel. Gut, 10,963-972.

Gorbach, S. L., Plaut, A. G., Nahas, L., and Weinstein, L. (1967). Studies of intestinal microflora. II. Microorganisms of the small intestine and their relations to oral and fecal flora. Gastroenterology, 53, 856-867.

Kauffmann, F. (1974). The serology of the coli group. Journal of Immunology, 57, 71-100.

Shooter, R. A., Cooke, E. M., Rousseau, S. A., and Breaden, A. L. (1970). Animal sources of common serotypes of Escherichia coli in the food of hospital patients. Lancet, 2, 226-228. 